\title{
Triazol-substituted titanocenes by strain-driven 1,3-dipolar cycloadditions
}

\author{
Andreas Gansäuer ${ }^{* 1}$, Andreas Okkel ${ }^{1}$, Lukas Schwach ${ }^{1}$, Laura Wagner ${ }^{2}$, Anja Selig $^{2}$ \\ and Aram Prokop ${ }^{3}$
}

Open Access

\author{
Full Research Paper \\ Address: \\ ${ }^{1}$ Kekulé-Institut für Organische Chemie und Biochemie der \\ Rheinischen Friedrich-Wilhelms-Universität Bonn, \\ Gerhard-Domagk-Straße 1, D-53121 Bonn, Germany, ${ }^{2}$ Medizinische \\ Klinik für Hämatologie, Onkologie und Tumorimmunologie Campus \\ Vichow Klinikum Charité Berlin, Augustenburger Platz 1, D-13353 \\ Berlin, Germany and ${ }^{3}$ Abteilung für Kinderonkologie /-hämatologie \\ Kinderkrankenhaus der Stadt Köln Amsterdamerstrasse 59, D-50735 \\ Köln, Germany \\ Email: \\ Andreas Gansäuer* - andreas.gansaeuer@uni-bonn.de \\ * Corresponding author \\ Keywords: \\ azides; click-chemistry; cycloadditions; cytotoxicity; titanocenes
}

Beilstein J. Org. Chem. 2014, 10, 1630-1637.

doi:10.3762/bjoc. 10.169

Received: 01 April 2014

Accepted: 27 June 2014

Published: 17 July 2014

This article is part of the Thematic Series "Chemical templates".

Guest Editor: S. Höger

(C) 2014 Gansäuer et al; licensee Beilstein-Institut. License and terms: see end of document.

\begin{abstract}
An operationally simple, convenient, and mild strategy for the synthesis of triazole-substituted titanocenes via strain-driven 1,3dipolar cycloadditions between azide-functionalized titanocenes and cyclooctyne has been developed. It features the first synthesis of titanocenes containing azide groups. These compounds constitute 'second-generation' functionalized titanocene building blocks for further synthetic elaboration. Our synthesis is modular and large numbers of the complexes can in principle be prepared in short periods of time. Some of the triazole-substituted titanocenes display high cyctotoxic activity against BJAB cells. Comparison of the most active complexes allows the identification of structural features essential for biological activity.
\end{abstract}

\section{Introduction}

Group 4 metallocenes and derivatives of $\mathrm{Cp}_{2} \mathrm{TiCl}_{2}$, in particular, continue to be in the focus of contemporary research as a promising class of cytotoxic compounds [1-10], as efficient reagents and catalysts [11-16], as organometallic gelators [17$20]$, and in their own right $[21,22]$. In order to further investigate and improve these properties it is mandatory to access as yet unexplored functional titanocenes. This is most easily achieved with modular, efficient, and general strategies for the synthesis of these complexes. Classical approaches with metala- tion at the end of the sequence usually do not meet these requirements. This is because introduction of functional groups is difficult due to the nucleophilicity of the cyclopentadienyl anions before metalation and the electrophilicity of titanium after metalation [21,22].

We have devised a conceptually different approach addressing these issues. It relies on the use of carboxylate-containing titanocene building blocks [23-25]. From these compounds the 
corresponding acid chlorides can be prepared by addition of $\mathrm{SOCl}_{2}$. The acid chloride group is more electrophilic than the $\left[\mathrm{TiCl}_{2}\right]$ fragment and therefore many titanocenes containing ligands with pending amide, ester, and ketone groups can be prepared with classical organic acylation reactions (Friedel-Crafts reaction, esterification, amide synthesis, Scheme 1). Some of these complexes have been used as organometallic gelators $[19,20]$, as a novel class of cytostatic compounds [26], and catalysts for unusual radical cyclizations [27-31]. The ketone and amide substituted catalysts are cationic due to the intramolecular coordination of the carbonyl group $[30,31]$. This feature is essential for the cytostatic and catalytic activity. Moreover, in the amide complexes hydrogen bonding of the $\mathrm{N}-\mathrm{H}$ bond to chloride or $\left[\mathrm{ZnCl}_{4}\right]^{2-}$ is a crucial structural feature [31]. The gelation ability of the neutral ester-substituted titanocenes critically depends on the steric demand of the substituents on the cyclopentadienyl ligands. The carboxylates are valuable complexes for mediating highly chemoselective Barbier type allylations [32,33].

These findings demonstrate that the properties of our functional titanocenes critically depend on both the direct environment of the Ti center and the periphery of the complex. Therefore, it is desirable to develop novel entries to titanocenes with even higher structural and functional diversity to improve the observed functions. An especially attractive approach is the use of already functionalized building blocks as starting materials in diversity oriented synthesis that increases the molecular complexity. Any synthetic methodology used in this context must take into account the sensitivity of the titanocene towards nucleophiles.
We decided to address these issues by employing cationic amide-substituted titanocenes as building blocks and straindriven 1,3-dipolar cycloadditions [34-40] as synthetic methodology for the preparation of such 'second-generation' functional titanocenes. This line of action seemed especially appealing for two reasons. First, the cationic amide titanocenes have already displayed interesting activity and therefore serve as our lead structures. Second, the strain-driven 1,3-dipolar cycloadditions have evolved as extremely mild reactions for the functionalization of complex molecules. Since no metal complexes are required to catalyze the 1,3-dipolar cycloaddition [41-43], the reaction can be even used for the functionalization of biomolecules in living systems and has therefore been called bioorthogonal $[34,35]$.

To the best of our knowledge, no examples of the Ti-containing substrates for our strategy, i.e., azide-functionalized titanocenes, have been reported in the literature. One aspect of our study is to establish if such complexes are stable and readily available in high yield. It should be noted that only a single example of a $\mathrm{Cu}$-catalyzed 1,3-dipolar cycloaddition with an alkyne-functionalized titanocene has been described [44]. Therefore, the properties of triazol-substituted titanocenes, the products of the 1,3dipolar cycloaddition, are also largely unexplored.

\section{Results and Discussion \\ Synthesis of the titanocenes Preparation of the starting materials}

We started our investigation with the preparation of azidesubstituted cationic titanocenes. To this end, the titanocene carboxylates 1-3 shown in Figure 1 were employed as

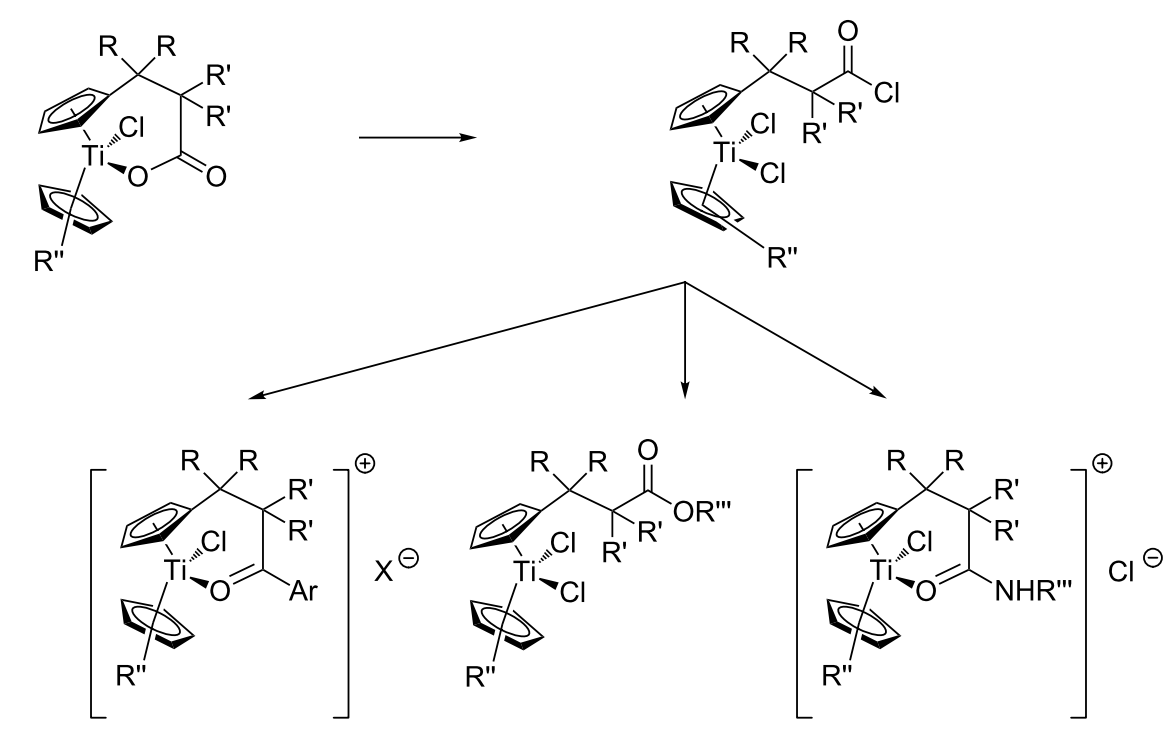


substrates because their substitution pattern should allow a first simple assessment of structure-activity relationships.
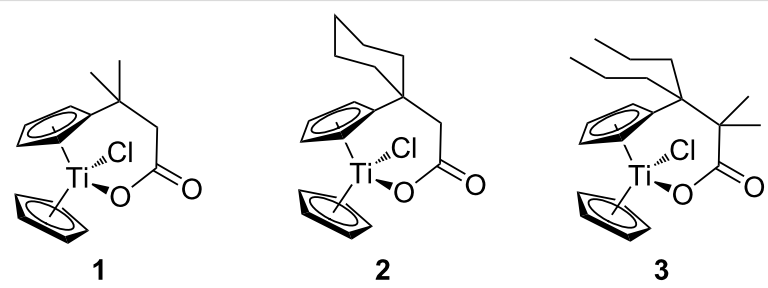

Figure 1: Carboxylates employed as titanocene starting materials for azide-substituted complexes.
The compounds A-D shown in Figure 2 were used as aminosubstituted azides. They are readily obtained from the corresponding diazides through a Staudinger reaction (see Supporting Information File 1 for details) $[45,46]$. As for the carboxylates the different tether lengths and substitution patterns of the arene allow to study the effect of substitution on the activity of the complexes. The ether tether in $\mathbf{B}$ serves as a model for PEG.

The titanocene carboxylates $\mathbf{1}-\mathbf{3}$ were transformed into the corresponding acid chlorides and then reacted with amino azides $\mathbf{A}-\mathbf{D}$ in the presence of $\mathrm{NaH}$ without purification of the acid chlorides. Typical results are summarized in Table 1.

$$
\mathrm{N}_{\mathrm{N}_{3}}
$$

A<smiles>N#CCc1ccc(CN)cc1</smiles>

c<smiles>[B]CCOCCOCCN</smiles><smiles>NCc1ccccc1CN</smiles>

D

$$
\begin{aligned}
& 2.5 \text { equiv } \mathrm{NaN}_{3} \\
& \mathrm{X} \sim \mathrm{R} \sim \mathrm{X} \stackrel{1.16 \mathrm{M}}{\longrightarrow} \\
& \mathrm{X}=\mathrm{Cl}, \mathrm{Br} \\
& \mathrm{H}_{2} \mathrm{O} / \mathrm{DMF}(1: 13) \\
& 24 \mathrm{~h}, 80^{\circ} \mathrm{C}
\end{aligned}
$$

0.95 equiv $\mathrm{PPh}_{3}$

$0.47 \mathrm{M}$

$\mathrm{Et}_{2} \mathrm{O} / \mathrm{EtOAc} / 5 \% \mathrm{HCl}$

$(1: 1: 1.5)$

$0{ }^{\circ} \mathrm{C}->\mathrm{rt}$

$24 \mathrm{~h}$

Figure 2: Azides employed in this study and conditions for their synthesis.

Table 1: Synthesis of cationic titanocenes containing azides (yield over two steps, see Supporting Information File 1 for details).

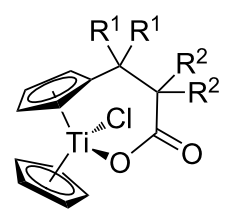

1) $\mathrm{SOCl}_{2}, \mathrm{CH}_{2} \mathrm{Cl}_{2}$

2) $\mathrm{H}_{2} \mathrm{~N}-\mathrm{R}-\mathrm{N}_{3}, \mathrm{NaH}$

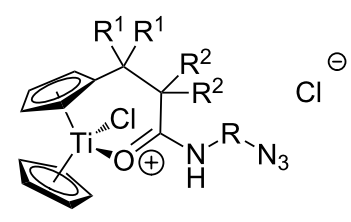

product

yield/[\%] 
Table 1: Synthesis of cationic titanocenes containing azides (yield over two steps, see Supporting Information File 1 for details). (continued)

$1, \mathrm{C}$

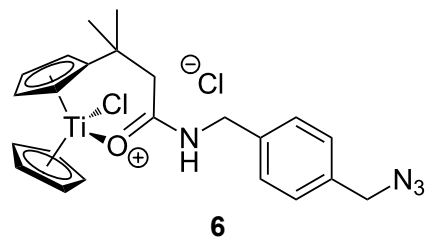

2, A

2, C

2, D
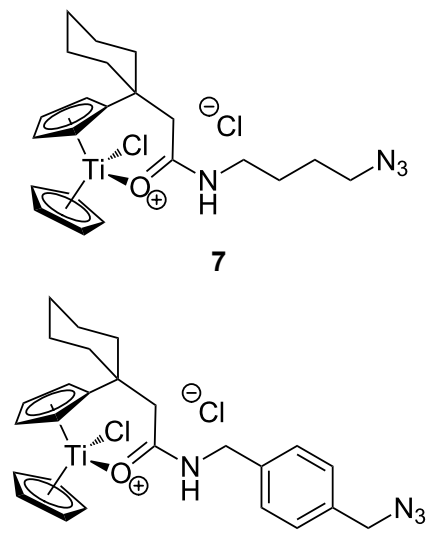

8

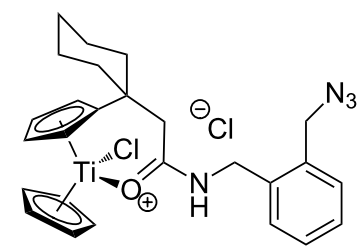

9

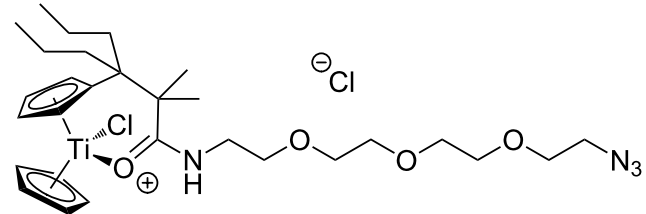

3, D
10

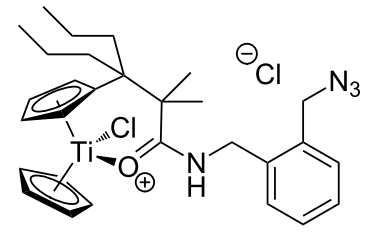

11
89

89
Gratifyingly, the acylation reactions proceed without problems and the azide-functionalized titanocenes can generally be obtained in good yields after $16 \mathrm{~h}$. The somewhat lower yields obtained with carboxylate 3 are probably due to an increased bulkiness of the ligand's substituents. It should be noted that polyether groups can be readily incorporated into cationic titanocenes. This suggests that the cationic titanocenes can be readily immobilized by covalent binding to PEG.

In general, our results clearly demonstrate that the azide group is compatible with cationic titanocenes. Moreover, it is obvious that large libraries of such titanocenes can be accessed from our carboxylates in short periods of time.

\section{Strain-driven 1,3-dipolar cycloadditions}

With the new titanocene building blocks in hand we turned our attention to their further functionalization through the straindriven 1,3-dipolar cycloaddition with cyclooctyne. The original conditions of Wittig [36], the reaction of cyclooctyne with phenyl azide, and the numerous applications pioneered by Bertozzi suggest that the reaction proceeds under mild conditions $[34,35,37-40]$. Therefore, we simply mixed the titanocenes 
and cyclooctyne in $\mathrm{CH}_{2} \mathrm{Cl}_{2}$ at room temperature. The concentration of the substrates was intentionally kept low $(0.1 \mathrm{M})$ to avoid a too intense evolution of heat. Typical examples of the reaction are summarized in Table 2 .

The results demonstrate that the strain-driven 1,3-dipolar cycloaddition is a convenient and very mild route to triazole-functionalized cationic titanocenes. The yields between $75 \%$ and
$92 \%$ are satisfying. It should be noted that the polyether-substituted complexes $\mathbf{1 3}$ and $\mathbf{1 7}$ are obtained in high yield. This opens further interesting perspectives for the immobilization of titanocene complexes.

\section{Cytotoxicity studies}

One of the pertinent features of titanocenes is their cytotoxicity [1-5]. Therefore, we investigated this particular property of our

Table 2: Strain-driven 1,3-dipolar cycloadditions between cyclooctyne and azide-functionalized titanocenes in $\mathrm{CH}_{2} \mathrm{Cl}_{2}(0.1 \mathrm{M})$.
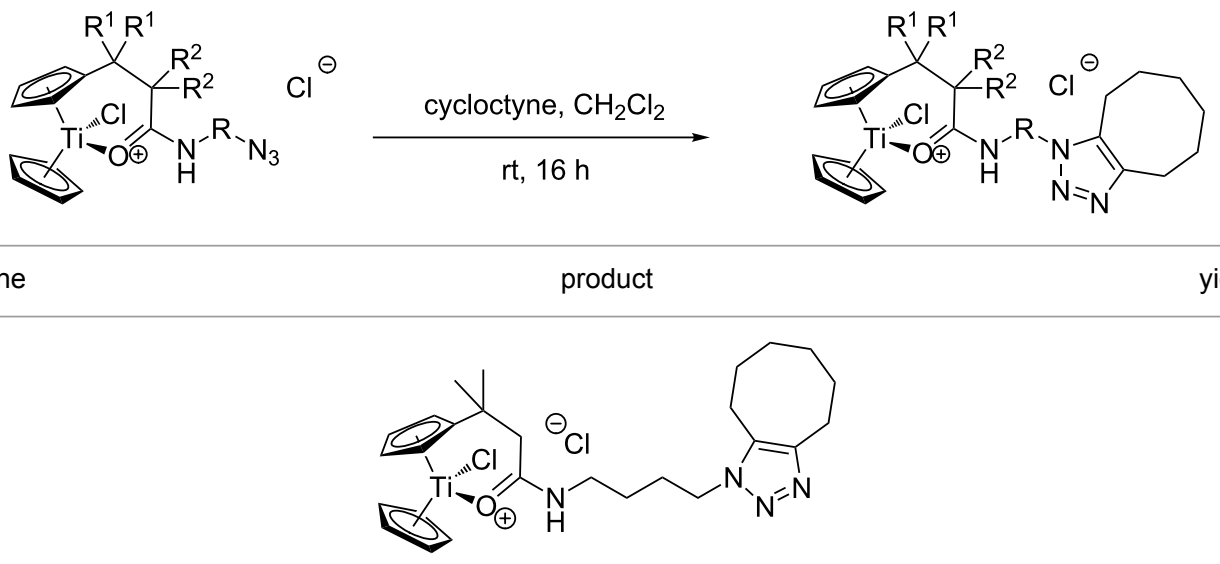

12
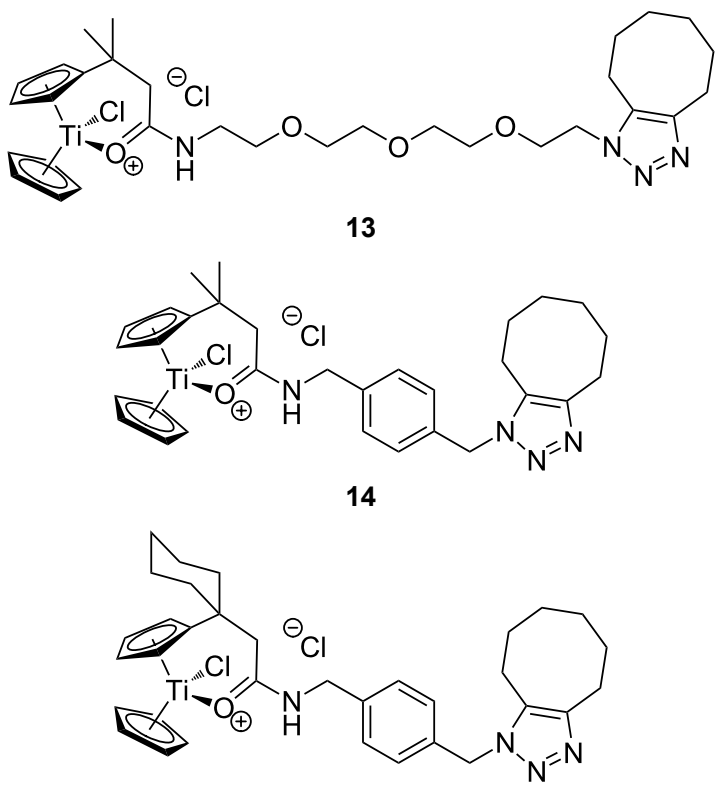

15

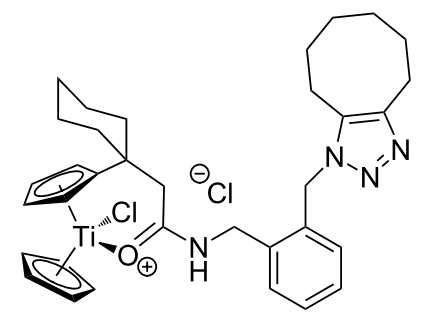


Table 2: Strain-driven 1,3-dipolar cycloadditions between cyclooctyne and azide-functionalized titanocenes in $\mathrm{CH}_{2} \mathrm{Cl}_{2}(0.1 \mathrm{M}) .($ continued)

10

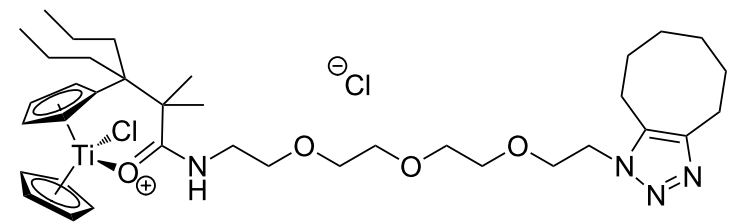

17

11

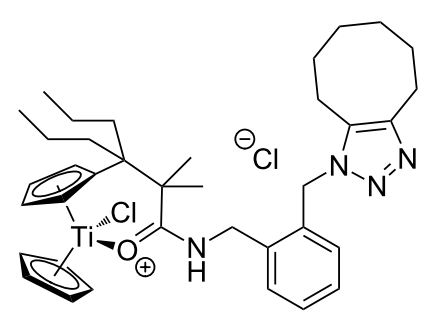

novel complexes. To guarantee comparability with a previous study [26] we discuss our results of the lymphoma cell line BJAB. Cell surface transmembrane receptor CD95, through which apoptosis can be induced, is expressed by BJAB cells. Cell death can be induced in these cells both by the extrinsic and the intrinsic apoptosis-signalling pathway [47-49]. Therefore, BJAB cells are well-suited for studying the induction of apoptosis by our cationic titanocenes [50-53]. It is logical to study apoptosis induction, expressed as $\mathrm{AC}_{50}$ values, instead of nonspecific cytotoxicity, which is usually reported as $\mathrm{LC}_{50}$ values, because cytotoxic drugs operate by specific induction of apoptosis. So we determined the $\mathrm{AC}_{50}$ values of our titanocenes, i.e., the concentrations causing specific apoptosis in $50 \%$ of lymphoma cells, counting all cells with membrane damage.

The azide-substituted complexes showed no significant apoptosis induction $\left(\mathrm{AC}_{50}>100 \mu \mathrm{M}\right)$. Introduction of the triazole ring through 1,3-dipolar cycloaddition markedly changes the activity of our titanocenes as a function of the substitution pattern. The most active complexes are highlighted in Figure 3.

Gratifyingly, 18, together with a ketone-substituted titanocene, displays the highest activity against the $\mathrm{BJ} A \mathrm{~B}$ cell line of our
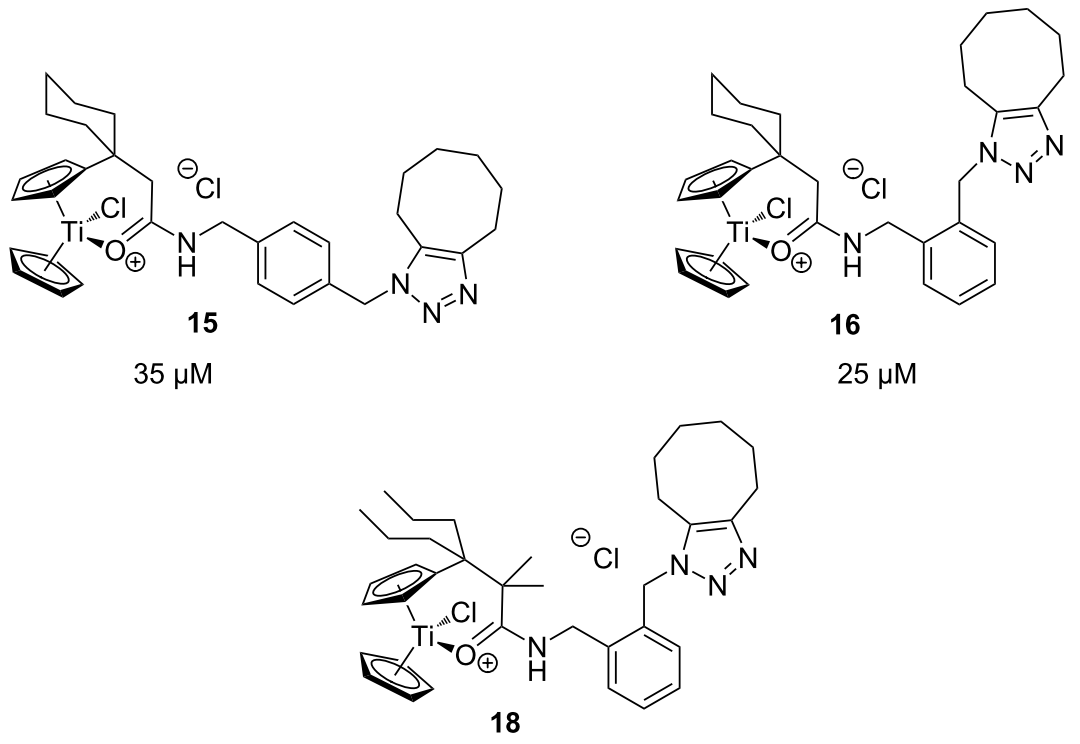

$12.5 \mu \mathrm{M}$

Figure 3: Most active titanocenes of this study and their $\mathrm{AC}_{50}$ values. 
cationic carbonyl-substituted titanocenes. Comparison of the three most active complexes also allows the identification of structural features essential for cytotoxic activity. First, a bulky substitution of the cyclopentadienyl ligand is favorable. Second, positioning of the triazol in close proximity - ortho-substitution in 16 leads to a lower $\mathrm{AC}_{50}$ value than para-substitution in $\mathbf{1 5}$ of the metal center enhances the biological activity.

\section{Conclusion}

In summary, we have devised an operationally simple, convenient, and mild strategy for the synthesis of triazole substituted titanocenes via strain-driven 1,3-dipolar cycloadditions between azide-functionalized titanocenes and cyclooctyne. It features the first synthesis of titanocenes containing azide groups. These compounds constitute functionalized 'second-generation' titanocene building blocks for further synthetic elaboration. Our synthesis is modular and large numbers of the complexes can in principle be prepared in short periods of time. Some of the triazole-substituted titanocenes display high cyctotoxic activity against BJAB cells. Comparison of the most active complexes allows the identification of structural features essential for biological activity.

Future studies will concentrate on the preparation of neutral and of enantiomerically pure triazole-substituted titanocenes, also via metal catalyzed cycloadditions, for further increasing the biological activity of the complexes and for applications in enantioselective [54,55] cyclizations [56-58].

\section{Supporting Information}

\section{Supporting Information File 1}

Experimental procedures and compound characterization, cytotoxicity studies.

[http://www.beilstein-journals.org/bjoc/content/ supplementary/1860-5397-10-169-S1.pdf]

\section{Acknowledgements}

We thank the DFG (SFB 624, 'Template - Funktionale chemische Schablonen', FOR 630, 'Biologische Funktion von Organometallverbindungen'), Dr. Kleist Stiftung Berlin, Robert-Koch Stiftung Berlin.

\section{References}

1. Buettner, K. M.; Valentine, A. M. Chem. Rev. 2012, 112, 1863-1881. doi:10.1021/cr1002886

2. Hartinger, C. G.; Metzler-Nolte, N.; Dyson, P. J. Organometallics 2012, 31, 5677-5685. doi:10.1021/om300373t

3. Tshuva, E. Y.; Ashenhurst, J. A. Eur. J. Inorg. Chem. 2009, 2203-2218. doi:10.1002/ejic.200900198
4. Strohfeldt, K.; Tacke, M. Chem. Soc. Rev. 2008, 37, 1174-1187. doi:10.1039/b707310k

5. Köpf-Maier, P.; Köpf, H. Chem. Rev. 1987, 87, 1137-1152. doi:10.1021/cr00081a012

6. Sirignano, E.; Saturnino, C.; Botta, A.; Sinicropi, M. S.; Caruso, A.; Pisano, A.; Lappano, R.; Maggiolini, M.; Longo, P. Bioorg. Med. Chem. Lett. 2013, 23, 3458-3462. doi:10.1016/j.bmcl.2013.03.059

7. Schur, J.; Manna, C. M.; Deally, A.; Köster, R. W.; Tacke, M.; Tshuva, E. Y.; Ott, I. Chem. Commun. 2013, 49, 4785-4787. doi:10.1039/c3cc38604j

8. Kater, L.; Claffey, J.; Hogan, M.; Jesse, P.; Kater, B.; Strauss, S.; Tacke, M.; Prokop, A. Toxicol. in Vitro 2012, 26, 119-124. doi:10.1016/j.tiv.2011.09.010

9. González-Pantoja, J. F.; Stern, M.; Jarzecki, A. A.; Royo, E.; Robles-Escajeda, E.; Varela-Ramírez, A.; Aguilera, R. J.; Contel, M. Inorg. Chem. 2011, 50, 11099-11110. doi:10.1021/ic201647h

10. Gao, L. M.; Vera, J. L.; Matt, J.; Meléndez, E. J. Biol. Inorg. Chem. 2010, 15, 851-859. doi:10.1007/s00775-010-0649-7

11. Carter, M. B.; Schiøtt, B.; Gutiérrez, A.; Buchwald, S. L. J. Am. Chem. Soc. 1994, 116, 11667-11670. doi:10.1021/ja00105a006

12. Pohlki, F.; Doye, S. Angew. Chem., Int. Ed. 2001, 40, 2305-2308. doi:10.1002/1521-3773(20010618)40:12<2305::AID-ANIE2305>3.0.CO ;2-7

13. Cuerva, J. M.; Justicia, J.; Oller-López, J. L.; Oltra, J. E. Top. Curr. Chem. 2006, 264, 63-91. doi:10.1007/128_025

14. Gansäuer, A.; Justicia, J.; Fan, C.-A.; Worgull, D.; Piestert, F. Top. Curr. Chem. 2007, 279, 25-52. doi:10.1007/128_2007_130

15. Gansäuer, A.; Fleckhaus, A.; Lafont, M. A.; Okkel, A.; Kotsis, K.; Anoop, A.; Neese, F. J. Am. Chem. Soc. 2009, 131, 16989-16999. doi:10.1021/ja907817y

16. Streuff, J.; Feurer, M.; Bichovski, P.; Frey, G.; Gellrich, U. Angew. Chem., Int. Ed. 2012, 51, 8661-8664. doi:10.1002/anie.201204469

17. Dastidar, P. Chem. Soc. Rev. 2008, 37, 2699-2715. doi:10.1039/b807346e

18. Piepenbrok, M.-O. M.; Lloyd, G. O.; Clarke, N.; Steed, J. W. Chem. Rev. 2010, 110, 1960-2004. doi:10.1021/cr9003067

19. Klawonn, T.; Gansäuer, A.; Winkler, I.; Lauterbach, T.; Franke, D.; Nolte, R. J. M.; Feiters, M. C.; Börner, H.; Hentschel, J.; Dötz, K. H. Chem. Commun. 2007, 1894-1895. doi:10.1039/b701565h

20. Gansäuer, A.; Winkler, I.; Klawonn, T.; Nolte, R. J. M.; Feiters, M. C.; Börner, H. G.; Hentschel, J.; Dötz, K. H. Organometallics 2009, 28, 1377-1382. doi:10.1021/om801022c

21. Halterman, R. L. Chem. Rev. 1992, 92, 965-994. doi:10.1021/cr00013a011

22. Qian, Y.; Huang, J.; Bala, M. D.; Lian, B.; Zhang, H.; Zhang, H. Chem. Rev. 2003, 103, 2633-2690. doi:10.1021/cr020002x

23. Gansäuer, A.; Franke, D.; Lauterbach, T.; Nieger, M. J. Am. Chem. Soc. 2005, 127, 11622-11623. doi:10.1021/ja054185r

24. Gansäuer, A.; Winkler, I.; Worgull, D.; Franke, D.; Lauterbach, T.; Okkel, A.; Nieger, M. Organometallics 2008, 27, 5699-5707. doi:10.1021/om800700c

25. Gansäuer, A.; Okkel, A.; Worgull, D.; Schnakenburg, G. Organometallics 2010, 29, 3227-3230. doi:10.1021/om100245r

26. Gansäuer, A.; Winkler, I.; Worgull, D.; Lauterbach, T.; Franke, D.; Selig, A.; Wagner, L.; Prokop, A. Chem.-Eur. J. 2008, 14, 4160-4163. doi:10.1002/chem.200800407

27. Gansäuer, A.; Lauterbach, T.; Geich-Gimbel, D. Chem.-Eur. J. 2004, 10, 4983-4990. doi:10.1002/chem.200400685 
28. Friedrich, J.; Dolg, M.; Gansäuer, A.; Geich-Gimbel, D.; Lauterbach, T. J. Am. Chem. Soc. 2005, 127, 7071-7077. doi:10.1021/ja050268w

29. Friedrich, J.; Walczak, K.; Dolg, M.; Piestert, F.; Lauterbach, T.; Worgull, D.; Gansäuer, A. J. Am. Chem. Soc. 2008, 130, 1788-1796. doi:10.1021/ja077596b

30. Gansäuer, A.; Worgull, D.; Knebel, K.; Huth, I.; Schnakenburg, G. Angew. Chem., Int. Ed. 2009, 48, 8882-8885. doi:10.1002/anie.200904428

31. Gansäuer, A.; Knebel, K.; Kube, C.; van Gastel, M.; Cangönül, A.; Daasbjerg, K.; Hangele, T.; Hülsen, M.; Dolg, M.; Friedrich, J. Chem.-Eur. J. 2012, 18, 2591-2599. doi:10.1002/chem.201102959

32. Jiménez, T.; Morcillo, S. P.; Martín-Lasanta, A.; Collado-Sanz, D.; Cárdenas, D. J.; Gansäuer, A.; Justicia, J.; Cuerva, J. M. Chem.-Eur. J. 2012, 18, 12825-12833. doi:10.1002/chem.201201534

33. Morcillo, S. P.; Martinez-Peragón, Á.; Jakoby, V.; Mota, A. J.; Kube, C.; Justicia, J.; Cuerva, J. M.; Gansäuer, A. Chem. Commun. 2014, 50, 2211-2213. doi:10.1039/c3cc49230c

34. Sletten, E. M.; Bertozzi, C. R. Angew. Chem., Int. Ed. 2009, 48, 6974-6998. doi:10.1002/anie.200900942

35. Jewett, J. C.; Bertozzi, C. R. Chem. Soc. Rev. 2010, 39, 1272-1279. doi:10.1039/b901970g

36. Wittig, G.; Krebs, A. Chem. Ber. 1961, 94, 3260-3275. doi:10.1002/cber.19610941213

37. Agard, N. J.; Prescher, J. A.; Bertozzi, C. R. J. Am. Chem. Soc. 2004, 126, 15046-15047. doi:10.1021/ja044996f

38. Gordon, C. G.; Mackey, J. L.; Jewett, J. C.; Sletten, E. M.; Houk, K. N.; Bertozzi, C. R. J. Am. Chem. Soc. 2012, 134, 9199-9208. doi:10.1021/ja3000936

39. Hudak, J. E.; Barfield, R. M.; de Hart, G. W.; Grob, P.; Nogales, E.; Bertozzi, C. R.; Rabuka, D. Angew. Chem., Int. Ed. 2012, 51, 4161-4165. doi:10.1002/anie.201108130

40. de Almeida, G.; Sletten, E. M.; Nakamura, H.; Palaniappan, K. K.; Bertozzi, C. R. Angew. Chem., Int. Ed. 2012, 51, 2443-2447. doi:10.1002/anie.201106325

41. Tornøe, C. W.; Christensen, C.; Meldal, M. J. Org. Chem. 2002, 67, 3057-3064. doi:10.1021/jo011148j

42. Rostovtsev, V. V.; Green, L. G.; Fokin, V. V.; Sharpless, K. B. Angew. Chem., Int. Ed. 2002, 41, 2596-2599. doi:10.1002/1521-3773(20020715)41:14<2596::AID-ANIE2596>3.0.CO ;2-4

43. Zhang, L.; Chen, X.; Xue, P.; Sun, H. H. Y.; Williams, I. D.; Sharpless, K. B.; Fokin, V. V.; Jia, G. J. Am. Chem. Soc. 2005, 127, 15998-15999. doi:10.1021/ja054114s

44. Zagerman, J.; Deally, A.; Metzler-Nolte, N.; Müller-Bunz, H.; Wallis, D.; Tacke, M. Polyhedron 2011, 30, 2387-2390. doi:10.1016/j.poly.2011.05.036

45. Golobov, Y. M.; Kasukhin, L. F. Tetrahedron 1992, 48, 1353-1406 doi:10.1016/S0040-4020(01)92229-X

46. Köhn, M.; Breinbauer, R. Angew. Chem., Int. Ed. 2004, 43, 3106-3116. doi:10.1002/anie.200401744

47. Bantel, H.; Engels, I. H.; Völter, W.; Schulze-Osthoff, K.; Wesselborg, S. Cancer Res. 1999, 59, 2083-2090.

48. Klener, P., Jr.; Anděra, L.; Klener, P.; Nečas, E.; Živný, J. Folia Biol. (Prague, Czech Repub.) 2006, 52, 34-44.

49. Meiler, J.; Schuler, M. Curr. Drug Targets 2006, 7, 1361-1369. doi:10.2174/138945006778559175

50. Wieder, T.; Prokop, A.; Bagci, B.; Essmann, F.; Bernicke, D.; Schulze-Osthoff, K.; Dörken, B.; Schmalz, H.-G.; Daniel, P. T.; Henze, G. Leukemia 2001, 15, 1735-1742. doi:10.1038/sj.leu.2402284
51. Diller, R. A.; Riepl, H. M.; Rose, O.; Frias, C.; Henze, G.; Prokop, A. Planta Med. 2007, 73, 755-761. doi:10.1055/s-2007-981545

52. Prokop, A.; Wrasidlo, W.; Lode, H.; Herold, R.; Lang, F.; Henze, G.; Dörken, B.; Wieder, T.; Daniel, P. T. Oncogene 2003, 22, 9107-9120. doi:10.1038/sj.onc.1207196

53. Rudner, J.; Lepple-Wienhues, A.; Budach, W.; Berschauer, J.; Friedrich, B.; Wesselborg, S.; Schulze-Osthoff, K.; Belka, C. J. Cell Sci. 2001, 114, 4161-4172.

54. Gansäuer, A.; Fan, C.-A.; Keller, F.; Karbaum, P. Chem.-Eur. J. 2007, 13, 8084-8090. doi:10.1002/chem.200701021

55. Gansäuer, A.; Shi, L.; Otte, M. J. Am. Chem. Soc. 2010, 132, 11858-11859. doi:10.1021/ja105023y

56. Gansäuer, A.; Pierobon, M. Synlett 2000, 1357-1359. doi:10.1055/s-2000-7133

57. Gansäuer, A.; Pierobon, M.; Bluhm, H. Synthesis 2001, 2500-2520. doi:10.1055/s-2001-18713

58. Barrero, A. F.; Quilez del Moral, J. F.; Sánchez, E. M.; Arteaga, J. F. Eur. J. Org. Chem. 2006, 1627-1641. doi:10.1002/ejoc.200500849

\section{License and Terms}

This is an Open Access article under the terms of the Creative Commons Attribution License (http://creativecommons.org/licenses/by/2.0), which permits unrestricted use, distribution, and reproduction in any medium, provided the original work is properly cited.

The license is subject to the Beilstein Journal of Organic Chemistry terms and conditions:

(http://www.beilstein-journals.org/bjoc)

The definitive version of this article is the electronic one which can be found at: doi:10.3762/bjoc. 10.169 